\title{
Evaluation of inbred maize lines for aluminum tolerance in nutrient solution
}

\author{
R. MAGNAVACA, \\ National Maize and Sorghum Research Center, EMBRAPA, C.P. 151, 35700 Sete Lagoas, M.G. \\ Brazil \\ C.O. GARDNER and R.B. CLARK \\ Department of Agronomy and U.S. Department of Agriculture, Agricultural Research Service, \\ University of Nebraska, Lincoln, NE 68583, USA
}

Key words $\mathrm{Al}$ and $\mathrm{P}$ levels to assess $\mathrm{Al}$ tolerance Brazilian and USA inbred lines Plant measurements for $\mathrm{Al}$ tolerance Zea mays

Summary Maize (Zea mays L.) inbred lines were grown in nutrient solution with different levels of $\mathrm{Al}$ and $\mathrm{P}$ to study their genetic variability for $\mathrm{Al}$ tolerance. Plant measurements for determining inbred line responses to $\mathrm{Al}$ were also evaluated. The best traits to assess maize for $\mathrm{Al}$ tolerance were seminal and adventitious root lengths.

Brazilian maize inbred lines were more tolerant to $\mathrm{Al}$ for the traits measured than USA inbred lines when grown in nutrient solution. Most inbred lines tested showed decreased root lengths, but a few Brazilian lines were not affected by the $\mathrm{Al}$ levels used. At higher $\mathrm{Al}$ levels most Brazilian lines were not affected as severely as the USA lines. Tolerance of the inbred lines to Al was increased by inclusion of $\mathrm{P}$ in nutrient solutions. The greatest Al-induced decrease in root length generally occurred at the lowest $\mathrm{P}$ level. The combination of $185 \mu \mathrm{mol} \mathrm{Al} \mathrm{L}^{-1}$ and $45 \mu \mathrm{mol} \mathrm{P} \mathrm{L}-1$ in nutrient solutions was the best combination of $\mathrm{Al}$ and $\mathrm{P}$ to evaluate maize genotypes for $\mathrm{Al}$ tolerance in this study.

\section{Introduction}

Acid soils appear frequently in tropical areas. Oxisols which are strongly weathered soils and have low cation exchange capacities, occupy $8.1 \%$ of the world land area $^{8}$. In tropical areas, Oxisols exhibit major mineral element deficiencies and toxicities; deficiencies of $\mathrm{P}, \mathrm{Ca}$, $\mathrm{Mg}$, and $\mathrm{Zn}$ are common, toxic exchangeable $\mathrm{Al}$ is usually high, and the fixation of $\mathrm{P}$ by soil particles is extensive. Oxisols, Ultisols, and Inceptisols are estimated to occupy approximately 1000 million hectares in the tropics ${ }^{24}$. This corresponds to $33 \%$ of the total potentially arable land area of the world useful for crop production without irrigation.

Kamprath ${ }^{17}$ indicated that the $\mathrm{Al}$ saturation in soils should be less than $45 \%$ for maximum growth of maize (Zea mays L.), but Olmos and $\mathrm{Camargo}^{20}$ found that $25 \% \mathrm{Al}$ saturation reduced maize yields. On a Brazilian acid Oxisol soil that had 55\% Al saturation, 363 inbred maize lines were evaluated for their response to acid soil toxicity ${ }^{1}$. The soil had received no lime applications but had received relatively high amounts of $\mathrm{N}$ and P. Fifteen days after planting 19\% of the inbred lines died and 45 
days later $70 \%$ of the inbred lines were dead. Decreases in maize yield due to $\mathrm{Al}$ toxicity have also been reported for Oxisols in Brazil ${ }^{9,10}$, for ferrallitic and ferruginous soils in Madagascar ${ }^{25}$; for Oxisols and Ultisols of Puerto Rico ${ }^{3}$; for Andosols from northeastern Japan ${ }^{23}$; and for Ultisols of Pennsylvania in the USA ${ }^{11}$.

Genetic variability in Al tolerance has been demonstrated among maize inbred lines, hybrids, and varieties for $\mathrm{Al}$ tolerance $\mathrm{e}^{1,2,6,10,16,22}$.In these studies, evaluations of maize germplasm for tolerance to $\mathrm{Al}$ were made in field experiments where plants were grown on acid soils, in greenhouse experiments where plants were grown in pots of acid soil, in germination studies where seeds were irrigated with Al-containing nutrient solutions in sand, and in studies where seedlings were grown in nutrient solutions with Al. The different approaches to assess A1 tolerance have been responsible for many of the conflicting results that have been reported for genotypic differences in tolerance to $\mathrm{Al}^{15}$. Screening techniques used for the assessment of $\mathrm{Al}$ tolerance must consider the appropriate combination of factors like concentrations of $\mathrm{Al}, \mathrm{Ca}, \mathrm{Mg}, \mathrm{P}$, and $\mathrm{K}$, the solution $\mathrm{pH}$, source of $\mathrm{N}$ (ammonium or nitrate), and temperature. The traits used to measure $\mathrm{Al}$ genotypic differences also need to be considered ${ }^{14}$.

The objectives of this research were to: (i) develop relatively easy and inexpensive techniques to evaluate seedlings of maize genotypes for $\mathrm{Al}$ tolerance; (ii) study genetic variation among homogeneous maize inbred lines for Al tolerance; and (iii) compare responses to tropical (Brazilian) and temperate (USA) maize inbred lines to Al.

\section{Material and methods}

\section{Growth of plants}

Seeds treated with captan [N-(trichloromethylthio)-4-cyclohexene-1,2-dicarboximide] were germinated seven days in rolled paper towels kept moist with aerated distilled water. The temperature was $27 \pm 1^{\circ} \mathrm{C}$ for $16 \mathrm{~h}$ with fluorescent lights (Agro-Lite cool-white, F40)* at $150 \mu \mathrm{E} \mathrm{m}^{-2} \mathrm{~s}^{-1}$ and $8 \mathrm{~h}$ of darkness at $19 \pm 1^{\circ} \mathrm{C}$. Seven-day-old uniform-sized seedlings without visual root injury were transferred to plastic plates containing either 126 (Experiment 1) or 42 (Experiment 2) plants per plate and grown in $6.5 \mathrm{~L}$ nutrient solution with treatments. Distilled water was added regularly to maintain volume. The initial $\mathrm{pH}$ of nutrient solutions was adjusted to 4.0 , monitored daily, and adjusted to 4.0 if needed with $1 \mathrm{NHCl}$ or $\mathrm{NaOH}$. Plants were grown in treatment solutions 10 days before experiments were terminated.

The composition of nutrient solutions used for growth of maize was ( $\mu$ mol element $\mathrm{L}^{-1}$ ): 10900 $\mathrm{NO}_{3}-\mathrm{N} ; 3500 \mathrm{Ca} ; 2300 \mathrm{~K} ; 1300 \mathrm{NH}_{4}-\mathrm{N} ; 850 \mathrm{Mg} ; 590 \mathrm{~S} ; 590 \mathrm{Cl} ; 25 \mathrm{~B} ; 9.1 \mathrm{Mn} ; 2.29 \mathrm{Zn} ; 0.88 \mathrm{Mo}$; $0.63 \mathrm{Cu} ; 77 \mathrm{Fe}$ as FeHEDTA (ferric hydroxethylethylenediaminetriacetate). Phosphorus and Al concentrations varied with the treatment. Aluminum was added to the nutrient solutions as $\mathrm{KAl}\left(\mathrm{SO}_{4}\right)_{2}$ and $\mathrm{P}$ as $\mathrm{KH}_{2} \mathrm{PO}_{4}$. Details of procedures used for growing plants in nutrient solution have been described ${ }^{5,15}$.

* Mention of a company, trademark, or proprietary product does not constitute a guarantee or warranty of the product by the University of Nebraska or the U.S. Department of Agriculture, and does not imply its approval to the exclusion of other products that may also be suitable. 
Growth conditions for Experiment 1 were $17 \mathrm{~h}$ light at $28 \pm 1^{\circ} \mathrm{C}$ and $7 \mathrm{~h}$ darkness at $23 \pm 1^{\circ} \mathrm{C}$ in a controlled environment chamber. Photosynthetic photon flux density (PPFD) was $350 \mu \mathrm{E} \mathrm{m}^{-2} \mathrm{~s}^{-1}$ at plant level $(60 \mathrm{~cm}$ below the lights). Lamps providing light were high pressure sodium (General Electric, Lucalux, LU4008) ${ }^{3}$ and metal halide (General Electric, multivapor, MV400 $)^{3}$.For Experiment 2, plants were grown in a controlled environment room with $16 \mathrm{~h}$ light at $27 \times 1{ }^{\circ} \mathrm{C}$ and $8 \mathrm{~h}$ darkness at $19 \pm 1^{\circ} \mathrm{C}$. Lamps providing light were fluorescent (Agro-Light cool-white, $\mathrm{F} 40)^{3}$ yielding $150 \mu \mathrm{E} \mathrm{m}^{-2} \mathrm{~s}^{-1}$ PPFD at plant height $(100 \mathrm{~cm}$ below the lamps).

\section{Plant measurements to assess Al tolerance}

In Experiment 1, only seminal roots were allowed to develop and the adventitious roots that had started to grow were removed. In Experiment 2, adventitious roots were allowed to develop. At the time seedlings in both experiments were put into treatment solutions, the initial seminal root lengths were measured for each plant. When experiments were terminated, the final seminal root length and the length of the longest adventitious root were measured on each plant. These and two other calculated root traits were used to assess plants for $\mathrm{Al}$ tolerance. Definition of each trait is:

Initial seminal root length (ISRL): The length of the primary seminal root when plants were transferred to treatment nutrient solutions;

Final seminal root length (FSRL): The length of the primary seminal root when experiments were terminated (plants grown 10 days in treatment solutions);

Relative seminal root length ( $R S R L$ ): Calculated by dividing FSRL by ISRL;

Net seminal root length (NSRL): Calculated by subtracting ISRL from FSRL; and

Longest adventitious root length ( $L A R L$ ): The length of the longest adventitious (synonymous with crown) root when experiments were terminated (plants grown 10 days in treatment solutions).

\section{Maize genotypes}

The USA inbred lines used were obtained from the maize breeding program of the Department of Agronomy, University of Nebraska, Lincoln even though several of the lines were originally developed in other states. The inbred lines used were A554, A635, B37, B73, C103, CI64, H84, Mo17, N7A, N28, N132, N139, N152, N156, N168, N174, and W117.

The Brazilian inbred lines used were developed at and belong to the collection of the National Maize and Sorghum Research Center, Sete Lagoas, M.G., Brazil, and brought to Nebraska. Each of these lines had undergone at least six generations of selfing and are identified as L69, L153, L297, M1001, M1002, M1003, M1004, M1005, M1007, M1009, M1010.

\section{Treatments, experimental design, and statistical analysis}

Experiment 1. Treatments included four Al levels $\left(0,74,148\right.$, and $\left.222 \mu \mathrm{mol} \mathrm{L}^{-1}\right)$ and 21 maize inbred lines (B37, L69, L153, L297, M1001, M1002, M1003, M1004, M1005, M1007, M1009, M1010, Mo17, N7A, N28, N132, N139, N152, N156, N168, and N174). A split-plot design was used with $\mathrm{Al}$ levels as whole plots and inbred lines as subplots. Whole plots were arranged in a randomized complete block design with three replications and subplots consisted of six plants each. Each nutrient solution container, therefore, constituted a whole plot and included 21 subplots of six plants each. The P level in nutrient solutions was $64 \mu \mathrm{mol} \mathrm{L}^{-1}$. Each plant of each subplot was evaluated for Al tolerance using ISRL, FSRL, NSRL, and RSRL, and subplot means were calculated. The analyses of variance were computed for each variable using subplot means of six plants.

Statistical analyses were performed using a fixed effects model. The Al levels sums of squares were partitioned into their linear and quadratic components. The $\mathrm{Al}$ level and genotype interactions sums of squares were likewise partitioned into genotype $\times \mathrm{Al}$ levels linear and genotypes Al levels quadratic components.

To test for linear and quadratic effects of $\mathrm{Al}$ on each genotype, a different subdivision of degrees of freedom was allocated according to the following model:

$$
Y_{i j n}=u+r_{i}+g_{n}+a_{j n}+e_{i j n},
$$

where $Y_{i j n}=$ the measurement of $n^{\text {th }}$ genotype in the $j^{\text {th }}$ Al level in the $\mathrm{i}^{\text {th }}$ replication, $\mathrm{u}=$ the overall mean effect, $r_{i}=$ the effect of the $i^{\text {th }}$ replication, $g_{n}=$ the effect of the $n^{\text {th }}$ genotype $a_{j n}=$ the effect 
Table 1. Mean relative seminal root length (RSRL), final seminal root length (FSRL), and net seminal root length (NSRL) of maize inbred lines grown in nutrient solution with $\mathrm{Al}$ (Experiment 1)

\begin{tabular}{|c|c|c|c|c|c|c|c|c|c|c|c|c|c|}
\hline \multirow{2}{*}{$\begin{array}{l}\text { Inbred } \\
\text { source }\end{array}$} & \multirow{2}{*}{$\begin{array}{l}\text { Inbred } \\
\text { line }\end{array}$} & \multicolumn{4}{|c|}{ RSRL } & \multicolumn{4}{|c|}{ FSRL $\left(m m\right.$ plant $\left.^{-1}\right)$} & \multicolumn{4}{|c|}{ NSRL (mm plant $\left.{ }^{-1}\right)$} \\
\hline & & $0^{\dagger}$ & 74 & 148 & 222 & 0 & 74 & 148 & 222 & 0 & 74 & 148 & 222 \\
\hline \multirow[t]{12}{*}{ Brazil } & L69 & 2.45 & 2.33 & 1.99 & 2.25 & 154 & 154 & 125 & 128 & 91 & 87 & 64 & 68 \\
\hline & L153 & 2.98 & 3.04 & 2.36 & & 217 & 20 & 18 & 153 & 144 & 138 & 109 & 81 \\
\hline & L297 & 3.82 & 3.75 & 2.23 & 1.87 & 244 & 247 & 156 & 110 & 173 & 178 & 83 & 50 \\
\hline & M1001 & 3.44 & 3.23 & 2.33 & 1.8 & 97 & 2 & 19 & 163 & 210 & 164 & 111 & 71 \\
\hline & M100 & 2.17 & 2.55 & 2.36 & 2.2 & 121 & 1 & 116 & 135 & 64 & & 66 & 74 \\
\hline & M 100 & 2.54 & 2.76 & 2.40 & 1.8 & 191 & 19 & 17 & 147 & 116 & 125 & 105 & 69 \\
\hline & M100 & 2.59 & 2.56 & 2.43 & 1.9 & 235 & 251 & 26 & 191 & 144 & 55 & 142 & 93 \\
\hline & M100 & 3.89 & 3.79 & 3.16 & 2.8 & 239 & 24 & 21 & 165 & 177 & 175 & 144 & 106 \\
\hline & M100 & 3.81 & 2.63 & 1.61 & 1.2 & 347 & 233 & 12 & 114 & 255 & 148 & 44 & 21 \\
\hline & M100 & 3.45 & 2.62 & 1.58 & 1.3 & 247 & 187 & 136 & 107 & 174 & 113 & 49 & 27 \\
\hline & M1010 & 4.44 & 3.26 & 2.67 & 1.73 & 308 & 245 & 205 & 144 & 233 & 168 & 129 & 63 \\
\hline & Mean & $\overline{3.23}$ & $\overline{2.96}$ & $\overline{2.28}$ & $\overline{1.93}$ & $\overline{236}$ & $\overline{213}$ & $\overline{171}$ & $\overline{142}$ & $\overline{162}$ & $\overline{140}$ & $\overline{95}$ & 66 \\
\hline \multirow[t]{11}{*}{ USA } & B73 & 1.97 & 1.65 & 1.35 & 1.32 & 194 & 175 & 131 & 121 & 95 & 69 & 33 & 29 \\
\hline & Mol7 & 2.99 & 2.59 & 1.99 & 1.64 & 167 & 143 & 103 & 96 & 108 & 85 & 51 & 37 \\
\hline & N7A & 2.18 & 1.81 & 1.25 & 1.16 & 195 & 149 & 123 & 107 & 105 & 65 & 25 & 15 \\
\hline & N28 & 3.48 & 3.00 & 1.94 & 1.42 & 249 & 260 & 126 & 109 & 171 & 172 & 55 & 32 \\
\hline & N132 & 2.37 & 2.28 & 1.51 & 1.29 & 240 & 205 & 154 & 134 & 139 & 114 & 51 & 30 \\
\hline & N139 & 2.07 & 1.94 & 1.51 & 1.33 & 226 & 216 & 156 & 143 & 116 & 105 & 54 & 35 \\
\hline & N152 & 278 & 2.32 & 1.56 & 1.36 & 311 & 278 & 182 & 153 & 197 & 157 & 66 & 43 \\
\hline & N156 & 3.08 & 2.71 & 1.81 & 1.44 & 262 & 225 & 171 & 125 & 174 & 137 & 76 & 37 \\
\hline & N168 & 2.39 & 2.12 & 1.78 & 1.40 & 248 & 224 & 161 & 138 & 147 & 121 & 72 & 40 \\
\hline & $\mathrm{N} 174$ & 3.22 & 2.08 & 1.69 & 1.43 & 206 & 174 & 135 & 108 & 138 & 88 & 59 & 32 \\
\hline & Mean & 2.65 & $\overline{2.25}$ & $\overline{1.64}$ & $\overline{1.38}$ & $\overline{230}$ & $\overline{205}$ & $\overline{144}$ & $\overline{123}$ & $\overline{139}$ & $\overline{111}$ & 54 & 33 \\
\hline \multicolumn{2}{|c|}{ Overall mean } & 2.96 & 2.62 & 1.98 & 1.67 & 233 & 209 & 158 & 133 & 151 & 126 & 74 & 50 \\
\hline
\end{tabular}

${ }^{\dagger} \mu \mathrm{mol} \mathrm{Al} \mathrm{L}-1$.

of the $\mathrm{j}^{\text {th }} \mathrm{Al}$ level within the $\mathrm{n}^{\text {th }}$ genotype, $\mathrm{e}_{\mathrm{ijn}}=$ the random pooled component of error associated with the $\mathrm{n}^{\text {th }}$ genotype at the $\mathrm{j}^{\text {th }} \mathrm{Al}$ level.

In this model, the pooled error mean squares provided only an approximated F-test for effects of $\mathrm{Al}$ levels within genotypes.

Experiment 2. Treatments included nine combinations of a $3^{2}$ factorial for three Al levels (37, 111 , and $\left.185 \mu \mathrm{mol} \mathrm{L}^{-1}\right)$ and three P levels $\left(22.5,45\right.$, and $\left.67.5 \mu \mathrm{mol} \mathrm{L}^{-1}\right)$. Seven maize inbred lines (A554, A635, CI64, L69, L153, L297, and Mo17) were used. Traits measured were ISRL, FSRL, RSRL, NSRL, and LARL. The individual measurement analyzed was the mean value of six plants per plot. The experimental design was a split-plot with $\mathrm{Al}$ and $\mathrm{P}$ combinations in the whole plots and genotypes allotted to the subplots. Two replications of whole plots were arranged in a randomized complete block design.

The statistical analyses were performed using a fixed effects model and dividing $\mathrm{Al}$ and P levels sums of squares into linear and quadratic components. The $\mathrm{Al} \times \mathrm{P}$ level interaction sums of squares were also subdivided into interactions involving the linear and quadratic effects of $\mathrm{Al}$ and $\mathrm{P}$.

\section{Results and discussion}

\section{Experiment 1}

The means for RSRL, FSRL, and NSRL and the analyses of variance 
Table 2. Analysis of variance for relative seminal root length (RSRL), final seminal root length (FSRL), and net seminal root length (NSRL) on inbred maize lines grown in nutrient solution with Al (Experiment 1)

\begin{tabular}{lcccc}
\hline Source of variation & df & \multicolumn{2}{l}{ Mean squares } & \\
\cline { 3 - 5 } & & RSRL & $\begin{array}{l}\text { FSRL } \\
\left(\mathrm{mm} \mathrm{plant}^{-1}\right)\end{array}$ & $\begin{array}{c}\text { NSRL } \\
\left(\mathrm{mm} \mathrm{plant}^{-1}\right)\end{array}$ \\
\hline Replications & 2 & 0.2201 & 2714.77 & $\begin{array}{c}2044.46 \\
\text { Al levels }\end{array}$ \\
$\quad 3$ & $21.7961^{* *}$ & $133091.67^{* *}$ & $133612.82^{* *}$ \\
$\quad$ Al quadratic & 1 & $64.0803^{* *}$ & $390368.00^{* *}$ & $392624.26^{* *}$ \\
$\quad$ Deviation & 1 & 0.0157 & 32.14 & 5.73 \\
Error a & 1 & 1.2922 & 8874.87 & 8208.46 \\
Lines & 6 & 0.5145 & 2207.64 & 2392.30 \\
Lines $\times$ Al levels & 20 & $2.5982^{* *}$ & $12620.94^{* *}$ & $9940.54^{* *}$ \\
$\quad$ Lines $\times$ Al linear & 60 & $0.3760^{* *}$ & $2369.23^{* *}$ & $2228.05^{* *}$ \\
$\quad$ Lines $\times$ Al quadratic & 20 & $0.9152^{* *}$ & $5408.34^{* *}$ & $5385.76^{* *}$ \\
$\quad$ Deviation & 20 & 0.1317 & $987.02^{*}$ & $776.56^{*}$ \\
Error b & 160 & 0.0812 & 712.34 & 521.83 \\
Total & 251 & 0.0972 & 519.32 & 459.37 \\
CV $(\%)$ & & 13.5 & 12.4 & 21.3 \\
\hline
\end{tabular}

*, ${ }^{* *}$ Statistical significance at $\alpha=0.05$ and $\alpha=0.01$.

for the USA and Brazilian inbred maize lines evaluated at four Al levels in Experiment 1 are presented in Tables 1 and 2. A consistency of results for the three traits was evident from the analyses of variance in Table 2. The linear responses to $\mathrm{Al}$ levels, differences among inbred lines, and the interaction of $\mathrm{Al}$ levels $\times$ lines were all statistically significant. Because of the significant $\mathrm{Al}$ levels $\times$ lines interactions, different analyses of variance were calculated and the linear and quadratic responses of $\mathrm{Al}$ levels were evaluated for each inbred line ${ }^{18}$.

The Brazilian inbred lines L69 and M1002 were not affected by Al level (Table 1). Each of the other lines decreased in seminal root length with increasing $\mathrm{Al}$ level in the nutrient solution. However, at the highest Al level $\left(222 \mu \mathrm{mol} \mathrm{L}^{-1}\right)$ the Brazilian lines L153, L297, M1001, M1003, M1004, M1005, and M1010 were affected less than the other inbred lines, especially when the RSRL and NSRL traits were used. Although differences at low levels of Al were noted, each of the USA and two of the Brazilian lines (M1007 and M1009) grew poorly at high levels of Al. In addition to the inbred lines L69 and M1002, the other inbred lines that grew relatively well under high $\mathrm{Al}$ stress should be desirable for production of hybrids to be grown on soils with high $\mathrm{Al}$ saturation.

The Brazilian inbred lines were generally more tolerant of Al than the USA inbred lines. The Brazilian lines were not developed from plants grown on soils with high levels of $\mathrm{Al}$ saturation, but the apparent random fixation of genes for tolerance to $\mathrm{Al}$ in inbred lines is an indication of the variability for tolerance in populations from which inbred 

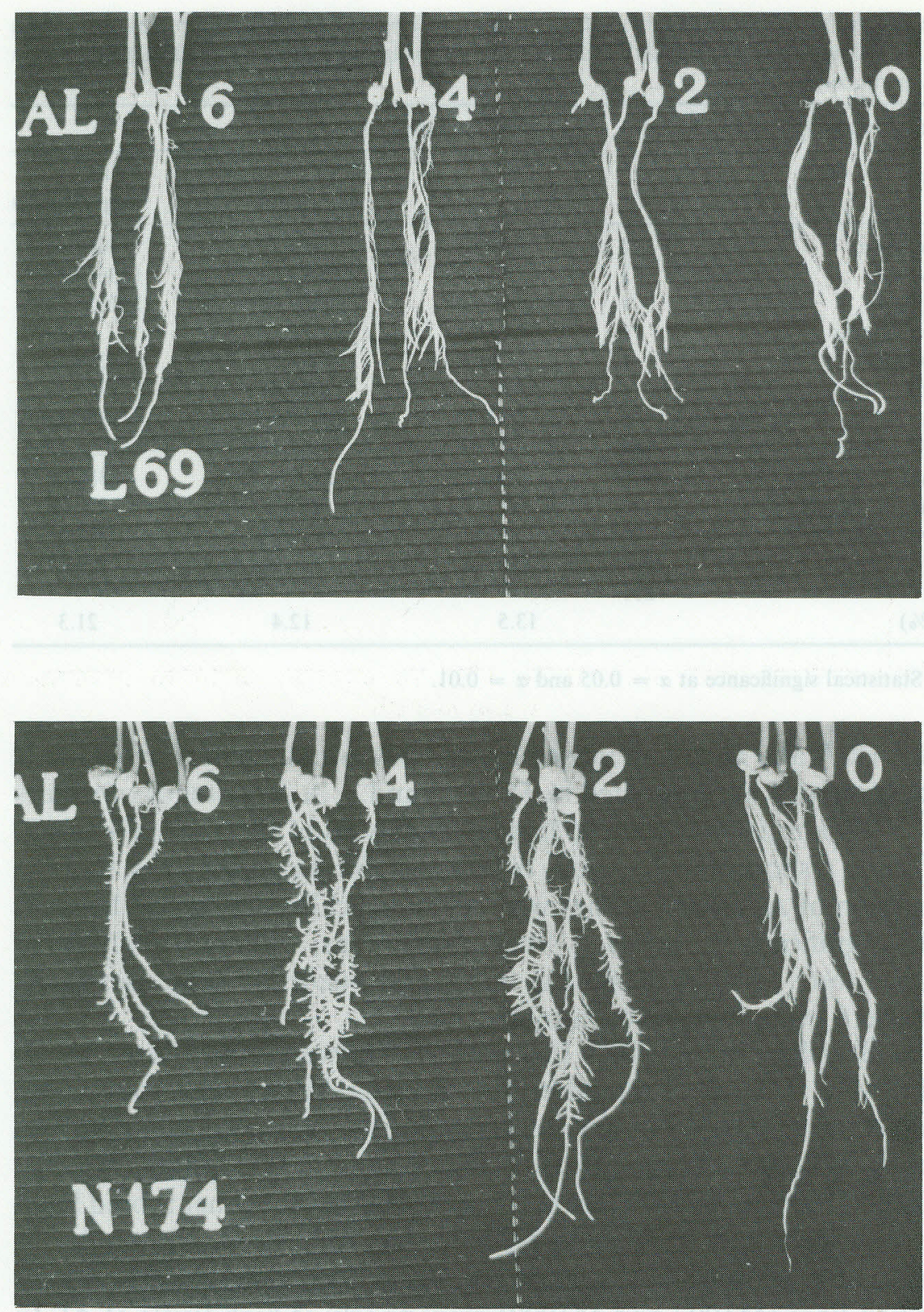

Fig. 1. Roots of the inbred maize lines L69 and N174 grown in nutrient solution at 222, 148, 74, and $0 \mu \mathrm{mol} \mathrm{Al} \mathrm{L}{ }^{-1}\left(6,4,2\right.$, and $\left.0 \mathrm{mg} \mathrm{Al} \mathrm{L}^{-1}\right)$ (left to right).

lines are developed. These lines had been tested for $\mathrm{Al}$ tolerance on acid soils in Brazil, and most of them showed high Al tolerance and grew well on the acid soils with high Al saturation".

The screening method used in this experiment showed considerable potential for large scale evaluations of inbred lines and progenies of 


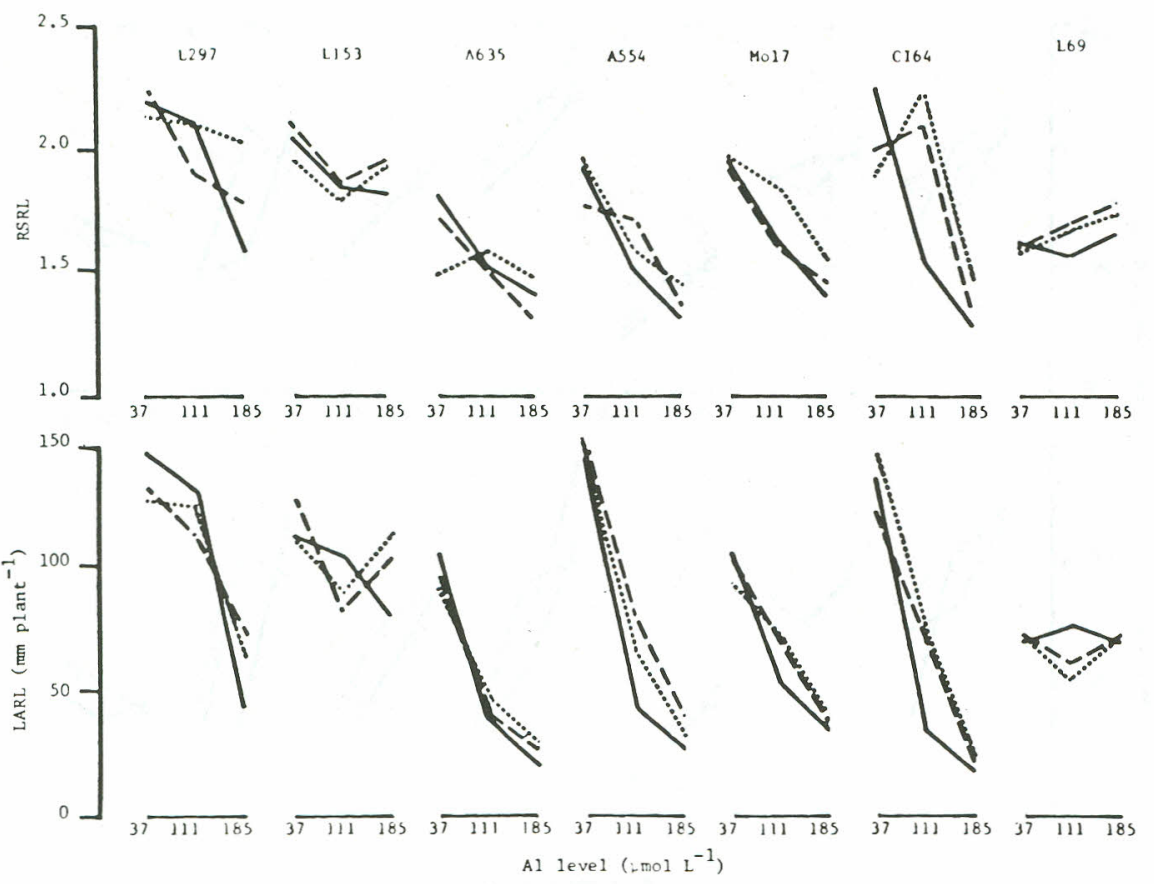

Fig. 2. Relative seminal root length (RSRL) and longest adventitious root length (LARL) of maize inbred lines grown at various levels of $\mathrm{Al}$ and $\mathrm{P}$ in nutrient solution (Experiment 2).

maize. By using six plants per plot, it was possible to evaluate 21 lines per container. Discrimination among inbred lines was relatively easy at $222 \mu \mathrm{mol} \mathrm{Al} \mathrm{L}{ }^{-1}$, especially when using RSRL to assess Al tolerance. The utilization of the high $\mathrm{Al}$ level used overcame the necessity of calculating relative values from measurements of the same lines in solutions without Al. Thus, the size of the experiment could be decreased to half. Figure 1 shows visual symptoms of Al toxicity for the tolerant L69 and the non-tolerant N174 maize inbreds.

\section{Experiment 2}

Seven inbred maize lines were evaluated at different levels of $\mathrm{Al}$ and P in nutrient solutions; three Brazilian lines (L69, L153, and L297) and four USA lines (A554, A635, CI64, and Mo17) were tested. The means of four traits (RSRL, LARL, FSRL, and NSRL) for each inbred line grown at various levels of $\mathrm{Al}$ and $\mathrm{P}$ are presented as response curves (Figs. 2 and 3). The analyses of variance of these four traits are presented in Table 3. Even though results varied slightly among the traits, significant differences were consistent among main effects of Al levels, lines, and the triple interaction of $\mathrm{Al} \times \mathrm{P} \times$ lines. Also the lack of significance of main effects of $\mathrm{P}$ and $\mathrm{P} \times$ line interaction was consistent. Only for RSRL was the $\mathrm{Al} \times \mathrm{P}$ interaction significant. 


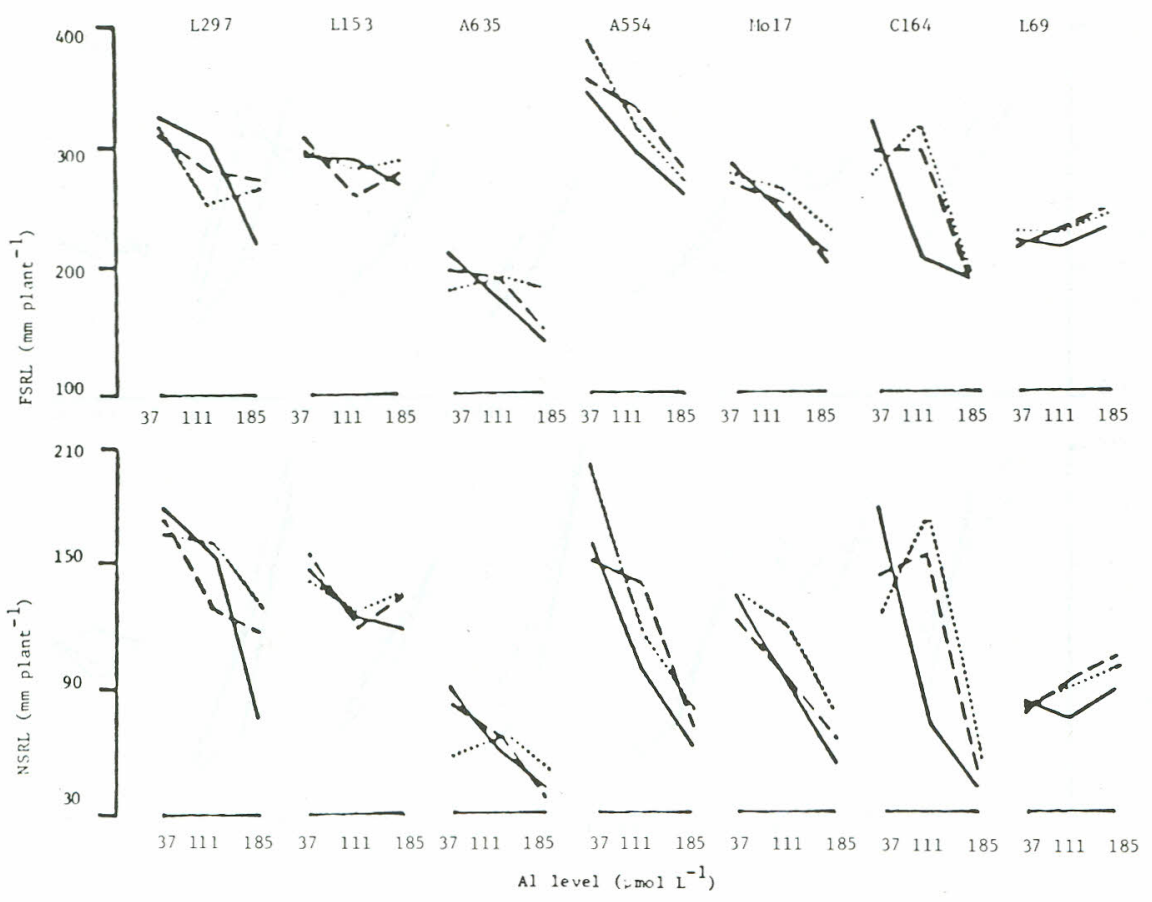

Fig. 3. Final seminal root length (FSRL) and net seminal root length (NSRL) of maize inbred lines grown at various levels of $\mathrm{Al}$ and $\mathrm{P}$ in nutrient solution (Experiment 2).

The inbred line L69 was not affected by Al level, and slight increases in root length at high levels of $\mathrm{P}$ were observed for each seminal root measurement. L69 was derived from a local Catete variety of the 'Cerrado' region in Brazil, and its response to Al level was similar in both Experiments 1 and 2.

The response of line L297 (derived from a cross of a tuxpeno line with the temperate single cross hybrid XL45) to Al levels depended on P level, especially for seminal root measurements. As the P level increased in the nutrient solution, the detrimental effects of $\mathrm{Al}$ decreased. The response of line L153, derived from a cross of a Catete population from Brazil and an Eto population from Colombia, for the four traits indicated some sensitivity to Al level, but somewhat independent of P level. However, $\mathrm{L} 153$ root lengths were greater than those of L69 at each $\mathrm{Al}$ and $\mathrm{P}$ level and greater than those of L297 at low P levels.

It was of interest to compare the results for these three Brazilian lines grown in nutrient solution with their grain yield response when grown in the field with three levels of Al saturation ${ }^{10,19}$. L69 was stable over each $\mathrm{Al}$ level in nutrient solution, but was intermediate in grain yield when grown in the field. L153 did not grow well at the high Al levels in nutrient solution, but two tons of lime ha ${ }^{-1}$ in the field was sufficient to promote 
Table 3. Analysis of variance of relative seminal root length (RSRL), longest adventitious root length (LARL), final seminal root length (FSRL), and net seminal root length (NSRL) of maize inbred lines grown in nutrient solution with three levels each of $\mathrm{Al}$ and $\mathrm{P}$ (Experiment 2)

\begin{tabular}{|c|c|c|c|c|c|}
\hline \multirow[t]{2}{*}{ Source of variation } & \multirow[t]{2}{*}{ df } & \multicolumn{4}{|c|}{ Mean squares } \\
\hline & & RSRL & $\begin{array}{l}\text { LARL } \\
\left(\mathrm{mm}_{\text {plant }}{ }^{-1}\right)\end{array}$ & $\begin{array}{l}\text { FSRL } \\
\left(\mathrm{mm} \mathrm{plant}^{-1}\right)\end{array}$ & $\begin{array}{l}\text { NSRL } \\
\left(\text { mm plant }^{-1}\right)\end{array}$ \\
\hline Replications & 1 & 0.0040 & 271.63 & 1225.78 & 257.14 \\
\hline Al levels & 2 & $1.2314^{* *}$ & $49749.11^{* *}$ & $29056.89^{* *}$ & $28618.88^{* *}$ \\
\hline Al linear & 1 & $2.4480^{* *}$ & $96425.19^{* *}$ & $57828.76^{* *}$ & $56732.01^{* *}$ \\
\hline Al quadratic & 1 & 0.0149 & $3073.02 * *$ & 285.02 & 505.75 \\
\hline P levels & 2 & 0.0476 & 393.92 & 1230.05 & 1530.45 \\
\hline $\mathrm{P}$ linear & 1 & 0.0953 & 624.30 & 2325.76 & 3012.01 \\
\hline $\mathrm{P}$ quadratic & 1 & 0.0000 & 163.53 & 134.35 & 48.89 \\
\hline $\mathrm{Al} \times \mathrm{P}$ & 4 & $0.0774^{*}$ & 185.08 & 856.26 & 1159.47 \\
\hline Al linear $\times$ P linear & 1 & $0.2379 * *$ & 565.79 & 2511.16 & 3001.78 \\
\hline Al linear $\times \mathrm{P}$ quadratic & 1 & 0.0012 & 172.02 & 190.72 & 172.02 \\
\hline Al quadratic $\times \mathrm{P}$ linear & 1 & 0.0668 & 1.17 & 323.15 & 1292.59 \\
\hline Al quadratic $\times \mathrm{P}$ quadratic & 1 & 0.0038 & 1.34 & 400.00 & 171.50 \\
\hline Error a & 8 & 0.0182 & 254.81 & 1322.03 & 596.82 \\
\hline Lines & 6 & $0.4775 * *$ & $6518.90^{* *}$ & $34879.68^{* *}$ & $13590.75^{* *}$ \\
\hline $\mathrm{Al} \times$ lines & 12 & $0.1396^{* *}$ & $3703.32 * *$ & $3382.19^{* *}$ & $3349.94 * *$ \\
\hline Al linear $\times$ lines & 6 & $0.2231^{* *}$ & $6176.50^{* *}$ & $5972.96^{* *}$ & $5753.90^{* *}$ \\
\hline Al quadratic $\times$ lines & 6 & $0.0561^{* *}$ & $1230.15^{* *}$ & 791.43 & $945.97 * *$ \\
\hline$P \times$ lines & 12 & 0.0171 & 136.16 & 241.08 & 246.09 \\
\hline $\mathrm{P}$ linear $\times$ lines & 6 & 0.0199 & 213.55 & 305.96 & 335.37 \\
\hline $\mathrm{P}$ quadratic $\times$ lines & 6 & 0.0142 & 58.78 & 176.21 & 156.81 \\
\hline $\mathrm{Al} \times \mathrm{P} \times$ lines & 24 & $0.0328 * *$ & $232.83^{*}$ & $937.41^{*}$ & $680.98 * *$ \\
\hline Al linear $\times \mathrm{P}$ linear $\times$ lines & 6 & 0.0201 & 193.99 & 627.74 & 426.28 \\
\hline Al quadratic $\times \mathrm{P}$ linear $\times$ lines & 6 & $0.0677^{* *}$ & $313.96^{*}$ & $2370.95^{* *}$ & $1434.57 * *$ \\
\hline Al linear $\times \mathrm{P}$ quadratic $\times$ lines & 6 & 0.0139 & 90.34 & 330.11 & 205.80 \\
\hline Al quadratic $\times \mathrm{P}$ quadratic $\times$ lines & 6 & 0.0297 & $333.02 *$ & 420.83 & $657.25^{*}$ \\
\hline Error b & 54 & 0.0152 & 126.47 & 514.38 & 280.34 \\
\hline Total & 125 & & & & \\
\hline CV $(\%)$ & & 7.03 & 13.98 & 8.77 & 15.07 \\
\hline
\end{tabular}

${ }^{*},{ }^{* *}$ Statistical significance at $\alpha=0.05$ and $\alpha=0.01$.

high grain yield. L297 responded adversely to Al levels in nutrient solution, but at high $\mathrm{Al}$ saturation in the field, grain yields were high. From these results, it was concluded that $\mathrm{Al}$ affected the high yielding L297 line by interfering with the uptake or utilization of P. This was not apparent for the other two Brazilian lines. At the highest level of Al, L29 and L153 were able to absorb and translocate $\mathrm{P}$ in a normal pattern. Relationships between $\mathrm{P}$ nutrition and $\mathrm{Al}$ tolerance have been repor$\operatorname{ted}^{2,6,7,12,13,21}$.

The four USA inbred lines A554, A635, CI64, and Mo17 had decreased root lengths with increasing levels of Al. The largest decreases generally occurred at the lowest level of P. The inbred line CI64 was unique for seminal root measurements in that when grown with high levels of $\mathrm{P}$, the addition of $111 \mu \mathrm{mol} \mathrm{Al} \mathrm{L}{ }^{-1}$ increased root length relative to the lowest level of $\mathrm{Al}$. However, root development decreased sharply with the addition of the higher $185 \mu \mathrm{mol} \mathrm{Al} \mathrm{L}{ }^{-1}$. Similar responses were 
reported for the inbred maize line $\mathrm{B} 57^{4}$. Root growth may also be inhibited by high levels of $\mathrm{P}^{5}$. The addition of $\mathrm{Al}$ to the solution may have inactivated some of the $\mathrm{P}$ in solution. Because of the biological and statistical significance of the $\mathrm{Al} \times \mathrm{P} \times$ line interaction, response curves for each trait of each line to the various levels of $\mathrm{Al}$ and $\mathrm{P}$ have been presented (Figs. 2 and 3).

Based on these results, $185 \mu \mathrm{mol} \mathrm{Al} \mathrm{L}{ }^{-1}$ and $45 \mu \mathrm{mol} \mathrm{P} \mathrm{L}{ }^{-1}$ in nutrient solutions were considered to be the best combination of $\mathrm{Al}$ and $\mathrm{P}$ to be used in genetic studies where 42 plants were grown per $6.5 \mathrm{~L}$ container for 10 days in treatment.

Although similarities among traits for assessing Al tolerance were noted in the maize inbreds, RSRL determined by the nutrient solution technique is recommended as the best of the traits to assess maize genotypes for $\mathrm{Al}$ tolerance. One concern was the effect of $\mathrm{Al}$ of root vigor during the seedling stage. RSRL was the only seminal root measurement that was corrected for ISRL. In Experiment 2, the correlations of ISRL with FSRL, NSRL, RSRL, and LARL were $0.68^{* *}, 0.31^{* *},-0.02$, and $0.21^{*}$, respectively. The NSRL and LARL analyses showed higher coefficients of variation compared to RSRL. NSRL and LARL would be recommended as second choices to RSRL as traits for assessing Al tolerance in nutrient solution. The FSRL could not be recommended as a suitable trait to assess $\mathrm{Al}$ tolerance.

\section{References}

1 Bahia A F C, Franca G E, Pitta G V E, Magnavaca R, Mendes J F, Bahia F G F T C and Pereira P 1978 Evaluation of corn inbred lines and populations in soil acidity conditions. pp 51-58. In XI Annu. Brazilian Maize Sorghum Conf., Piracicaba, S.P., Brazil. (In Portuguese)

2 Bahia A F C, Magnavaca R, Vasconcellos C A, Bahia F G F T C, Pitta G V E and Naspolini V 1979 Response curves to lime and phosphorus of corn hybrids in soil with high acidity. p 86. In XII Annu. Brazilian Maize Sorghum Conf., Goiania, GO., Brazil. (In Portuguese)

3 Brenes E and Pearson R W 1973 Root responses of three Gramineae species to soil acidity in an Oxisol and an Ultisol. Soil Sci. 116, 295-302.

4 Clark R B 1977 Effect of aluminum on growth and mineral elements of Al-tolerant and Al-intolerant corn. Plant and Soil 47, 653-662.

5 Clark R B 1982 Nutrient solution growth of sorghum and corn in mineral nutrition studies. J. Plant Nutr. 5, 1039-1057.

6 Clark R B and Brown J C 1974 Differential mineral uptake by maize inbreds. Commun. Soil Sci. Plant Anal. 5, 213-227.

7 Clark R B and Brown J C 1974 Differential phosphorus uptake by phosphorus-stressed corn inbreds. Crop Sci. 14, 505-508.

8 Dudal R 1976 Inventory of the major soils of the world with special reference to mineral stress hazards. pp 3-13. In Plant Adaptation to Mineral Stress in Problem Soils. Ed. M J Wright. Cornell Univ. Agric. Exp. Stn., Ithaca, NY.

9 EMBRAPA (Brazilian Department of Agriculture Research) 1978 Cerrado Agricultural Research Center Tech. Rep. 1976-1977. EMBRAPA, Brasilia, D.F. Brazil. (In Portuguese)

10 EMBRAPA (Brazilian Department of Agricultural Research) 1980 National Maize and 
Sorghum Research Center Tech. Rep. 1979. EMBRAPA, Brasilia, D.F., Brazil. (In Portuguese)

11 Fox R H 1979 Soil pH, aluminum saturation, and corn grain yield. Soil Sci. 127, 330-334.

12 Foy C D and Brown J C 1964 Toxic factors in acid soils. II. Differential aluminum tolerance of plant species. Soil Sci. Soc. Am. Proc. 28, 27-32.

13 Foy C D, Chaney R L and White M C 1978 The physiology of metal toxicity in plants. Annu. Rev. Plant Physiol. 29, 511-566.

14 Furlani P R 1981 Effects of aluminum on growth and mineral nutrition of sorghum genotypes. Ph.D. Dissertation, Univ. of Nebraska, Lincoln. Diss. Abstr. 42, 1260B.

15 Furlani P R and Clark R B 1981 Screening sorghum for aluminum tolerance in nutrient solution. Agron. J. 73, 587-594.

16 Garcia Jr. O. da Silva W J and Massei M A S 1979 An efficient method for screening maize inbreds for aluminum tolerance. Maydica 24, 75-82.

17 Kamprath E J 1972 Soil acidity and liming. pp 136-149. In Soils of the Humid Tropics. Nat. Acad. Sci., Washington, DC.

18 Magnavaca R 1982 Genetic variability and the inheritance of aluminum tolerance in maize (Zea mays L.). Ph.D. Diss. Univ. of Nebraska, Lincoln. Diss. Abstr. 43, 2073B (1983)

19 Naspolini V, Bahia A F C, Viana R T, Gama E E G, Vasconcellos C A and Magnavaca R 1981 Performance of inbreds and single crosses of maize in soils under 'cerrado' vegetation. Ciencia Cultura 33, 722-727. (In Portuguese)

20 Olmos I L and Camargo M N 1976 Incidence of aluminum toxicity in Brazilian soils: Its characterization and distribution. Ciencia Cultura 28, 171-180. (In Portuguese)

21 Rasmussen H P 1968 The mode of entry and distribution of aluminum in Zea mays: Electron microprobe $x$-ray analysis. Planta 81, 28-37.

22 Rhue R D and Grogan C O 1977 Screening corn for Al tolerance using different $\mathrm{Ca}$ and $\mathrm{Mg}$ concentrations. Agron. J. 69, 775-760.

23 Saigusa M, Shoji S and Takahshi T 1980 Plant root growth in acid Andosols from northeastern Japan. 2. Exchange acidity $Y_{1}$ as a realistic measure of aluminum toxicity potential. Soil Sci. $130,242-250$.

24 Van Wambeke A 1976 Formation, distribution and consequences of acid soils in agricultural development. pp 15-24. In Plant Adaptation to Mineral Stress in Problem Soils. Ed. M J Wright. Cornell Univ. Agric. Exp. Stn., Ithaca, NY. 25 Velly J 1974 Observation on the acidification of some soils in Madagascar. J. Agron. Trop. 12, 1249-1262. 